\title{
Data Base Akademik Terpadu Untuk Mendukung Sistem Monitoring Perkuliahan
}

\author{
Eriya, Risna Sari \\ Jurusan Teknik Informatika dan Komputer, \\ Politeknik Negeri Jakarta \\ Jl. Siwabessy, Kampus UI Depok, (021)7863534 \\ eriya@tik.pnj.ac.id, risna.sari@tik.pnj.ac.id
}

Diterima : 25 Februari 2020. Disetujui: 4 Maret 2020. Dipublikasikan: 29 Mei 2020

\begin{abstract}
Student achievements and academic processes need to be monitored and evaluated continuously to see the success of students and study programs in achieving predetermined educational goals. This monitoring and evaluation certainly required complete and comprehensive data for all academic activities. The problem that often arises is the lack of comprehensive data. For this reason, an integrated academic database is needed. An integrated database system is a centralized data storage medium for managing data and information. Integrated database development using database design methodology. With this database system, it will facilitate study programs in obtaining quality information for decision making and policies related to the academic process and study program future.
\end{abstract}

Keywords: Academic system, database system, integrated system, academic database

Abstrak - Prestasi dan proses perkuliahan mahasiswa perlu dimonitoring dan dievaluasi secara terus menerus untuk melihat keberhasilan mahasiswa dan program studi dalam mencapai tujuan pendidikan yang telah ditentukan. Monitoring dan evaluasi ini tentu membutuhkan data yang lengkap dan menyeluruh untuk semua kegiatan academic. Permasalahan yang sering muncul adalah tidak tersedianya data yang komprehensif. Untuk itu diperlukan sebuah database academic terpadu. System database terpadu merupakan sebuah media penyimpanan data secara terpusat untuk mengelola data dan informasi. Pengembangan database terpadu menggunakan design database methodology. Dengan adanya system database ini, akan memudahkan program studi dalam memperoleh informasi yang berkualitas untuk pengambilan keputusan dan kebijakankebijakan terkait proses perkuliahan dan pengembangan program studi ke depan

Kata kunci: sistem database, sistem terintegrasi, database terintegrasi, database akademik

\section{PENDAHULUAN}

Monitoring dan evaluasi proses perkuliahan merupakan kegiatan rutin yang harus dilakukan oleh program studi setiap semester. Ini penting dilakukan untuk mengukur sejauh mana program studi mampu mencapai tujuan pendidikan yang telah ditetapkan. Setiap tahun program studi juga harus membuat laporan evaluasi diri untuk menggambarkan kondisi program studi pada tahun tersebut, sehingga bisa diusulkan program-program pengembangan program studi ke depannya.

Monitoring dan evaluasi ini tentu membutuhkan data yang lengkap dan menyeluruh untuk semua kegiatan academik. Permasalahan yang sering muncul adalah tidak tersedianya data yang lengkap dan komprehensif. Hal ini tentu akan menjadi kendala sehingga proses monitoring dan evaluasi perkuliahan tidak dapat dilakukan secara efisien dan efektif. Sistem database akademik terpadu merupakan sebuah solusi yang dapat membantu program studi dalam menyediakan data dan informasi yang berkualitas untuk kebutuhan tersebut.

Database adalah salah satu komponen kunci dari setiap aplikasi dan layanan yang berpusat pada data [1]. Database merupakan kumpulan data yang diorganisasikan untuk melayani banyak aplikasi secara efisien dengan memusatkan data pada satu lokasi, satu database dapat melayani beberapa aplikasi [2]. Sistem database terpadu dapat melakukan penyimpanan data secara lengkap kedalam sebuah database sehingga berdampak pada penyajian data, informasi dengan cepat dan akurat dalam mendapatkan kembali informasi tersebut. Sistem terpadu berfungsi sebagai sarana atau media penyimpanan data dan informasi yang memiliki keserderhanaan, kehandalan dan portabilitas yang tinggi [3].

Pengembangan database yang berhubungan dengan pendidikan secara substantial sangat penting untuk analisis data dan penemuan pengetahuan dalam bidang Pendidikan. Data institusional universitas sangat bervariasi yang perlu distandarisasikan. Di US telah dikembangkan 
Educational Data System yang komprehensif dan terstandarisasi [4].

Berdasarkan permasalahan yang ada, maka paper ini mengusulkan sebuah database akademik terpadu guna mendukung sistem monitoring dan evaluasi perkulihan mahasiswa. database ini kedepannya juga dapat digunakan sebagai sumber data untuk analisis dan penemuan pengetahuan sehingga dapat memprediksi tingkah laku dan performance mahasiswa [5] [6] [7].

\section{TINJUAN PUSTAKA}

\section{A. Sistem database}

Organisasi baik publik atau swasta, kecil ataupun besar tergantung pada Sistem Manajemen Basis Data (DBMS) untuk menangani operasional mereka, Data-data disimpan dalam database. Kombinasi data dan program untuk mengakses data dikenal sebagai database[8]. Database merupakan kumpulan data yang diorganisasikan untuk melayani banyak aplikasi secara efisien dengan memusatkan data pada satu lokasi, satu database dapat melayani beberapa aplikasi [2]. Sistem database terpadu dapat melakukan penyimpanan data secara lengkap ke dalam database sehingga berdampak pada penyajian data, informasi dengan cepat dan akurat dalam mendapatkan kembali informasi tersebut. Sistem terpadu berfungsi sebagai sarana atau media penyimpanan data dan informasi yang memiliki keserderhanaan, kehandalan dan portabilitas yang tinggi. Oleh sebab itu, sistem terpadu dapat meningkatkan jaminan ketersediaan data, mendokumentasikan data, serta mempermudah pencarian informasi yang dibutuhkan oleh pengguna [3]. Sistem database terpadu memiliki keunggulan yaitu[9]:

1. Integritas data lebih maksimal dan redundansi data dapat diminimalkan, sehingga data menjadi akurat dan konsisten dalam meningkatkan keandalan data.

2. Keamanan data lebih terjaga.

3. Pelestarian data akan menjadi lebih baik karena pengelola dilakukan terpusat.

4. Pengguna lebih mudah untuk mendapatkan data dan informasi karena kesederhanaan dalam desain database tunggal.

5. Portabilitas data dan administrasi database secara umum lebih mudah.

6. Efektifivas penggunaan daya listrik, sumber daya manusia dan biaya pemeliharaan sistem database dapat dioptimalkan.

7. Semua informasi dapat diakses pada saat yang sama dari lokasi yang berbeda

\section{B. Desain dan Modeling Database}

Untuk membuat sebuah database, harus dipahami hubungan antar data, tipe data yang akan dikelola dalam database, bagaimana data digunakan serta bagaimana organisasi membutuhkan dan mengelola data dari perspektif perusahaan secara luas. Database memerlukan desain konseptual dan desain fisikal [2].

Desain konseptual menjelaskan bagaimana elemen data dalam database dikelompokkan. Proses desain mengidentifikasi hubungan antar elemen data dan cara yang paling efisien untuk mengelompokkan elemen data guna memenuhi kebutuhan informasi bisnis[9].

Pemodelan database secara konseptual digambarkan dengan Entity Relationship Diagram (ERD). ERD adalah sebuah diagram yang menggambarkan hubungan antar entitas data yang ada dalam database [2]. Dengan menggunakan diagram ERD, database designer dapat mengkonversi informasi ini untuk membangun table-tabel dalam database [10].

Beberapa database dikembangkan dengan pendekatan berorientasi objek (OODB) menggunakan lingkungan pemrograman, OODB ini dirancang menggunakan tool UML (Unified Modeling Language) [11].

\section{METODOLOGI PENELITIAN}

Metodologi penelitian menggambarkan tahapan proses, metode dan tools (alat bantu) yang digunakan dalam melakukan penelitian agar dapat berjalan dengan baik dan tujuan yang telah ditetapkan dapat tercapai. Metodologi pengembangan database mengadopsi database design process [1]. Adapun tahapannya dapat digambarkan sebagai berikut :

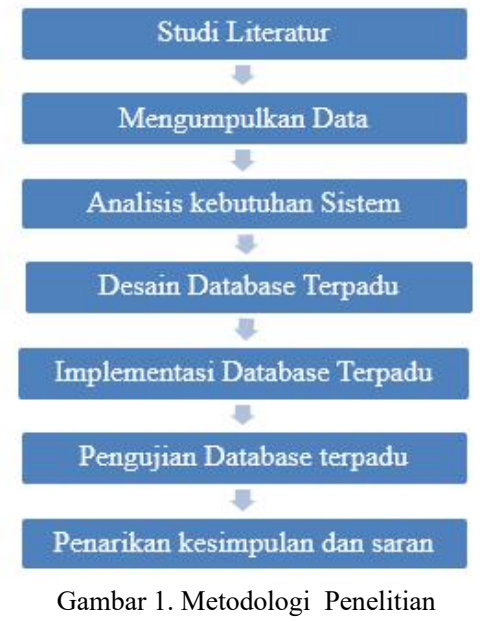

Metodologi penelitian dimulai dengan merumuskan masalah, kemudian melakukan studi literatur, megumpulkan data. Data dikumpulkan melalui wawancara, FGD (Focus Group Discussion), serta mengumpulkan data-data sekunder yang dimiliki oleh program studi. Kegiatan dilanjutkan 
dengan dengan menganalisis kebutuhan system database dengan mengidentifikasi semua entitas data yang dibutuhkan. Kebutuhan data akan dimodelkan secara logical menggunakan ERD. Kemudian dilanjutkan dengan desain fisikal menggunakan database relasional. Selanjutnya dilakukan implementasi database menggunakan Oracle 18c. Database yang terbentuk diuji dengan metode white box dan black box testing. Pengujian dilakukan untuk melakukan validasi terhadap database yang dibuat.

\section{HASIL DAN PEMBAHASAN}

\section{A. Analisis Kebutuhan Sistem}

Analisis kebutuhan system bertujuan untuk mendefenisikan kebutuhan database akademik. Dimulai dengan menganalisis proses akademik untuk mempelajari dan memahami serangkaian kegiatan akademik yang dilakukan oleh program studi dalam memberikan pelayanan kepada stakeholder-nya dalam hal ini mahsiswa dan dosen. Dengan melakukan analisis, setiap proses akademik dapat dievaluasi apakah sudah berjalan dengan dengan baik dan efisien atau belum. Pada penelitian ini analisis proses akademik difokuskan pada proses pelayanan administrasi akademik pada Program Studi Teknik Informatika (TI). Adapun Proses bisnis dari proses akademik dapat diuraikan sebagai berikut:

1. Proses penetapan kurikulum terdiri dari

a. Penetapan Matakuliah

b. Penetapan Silabus

2. Proses penetapan kalender akademik

3. Proses Perkuliahan, terdiri dari

a. Penetapan semester dan Tahun Aakdemik

b. Proses penetapan dosen pengampu

c. Proses penyusunan jadwal perkuliahan

1) Penentuan Kelas

2) Penentuan Jadwal

3) Penentuan Ruang

d. Proses Pelaksanaan Perkuliahan

1) Proses kuliah tatap muka dan praktikum

2) Proses Praktek Kerja Lapangan (PKL)

- Bimbingan PKL

- $\quad$ Sidang PKL

3) Proses skripsi

- Seminar Proposal

- Bimbingan Skripsi

- $\quad$ Sidang Skripsi

4. Proses evaluasi akademik

a. Proses pelaksanaan ujian

b. Proses pengolahan nilai mahasiswa

5. Pelaporan Akdemik

a. Laporan Absensi Mahsiswa

b. Laporan Kehadiran Dosen

\section{c. Laporan Kelulusan Mahasiswa}

\section{B. Analisis Entitas Data Akademik}

Entitas data akademik merupakan entitas data yang dihasilkan dari setiap proses akademik yang terjadi. Entitas data perlu diidentifikasi satu persatu dari masing-masing proses akademik yang kemudian akan direlasikan satu sama lainnya sehingga menjadi sebuah system database terpadu. Sistem ini nantinya akan digunakan sebagai pusat data untuk semua aplikasi sistem informasi akademik dalam monitoring perkuliahan mahasiswa. Adapun daftar Entitas dan Atribut pada sistem database Terpadu dapat dilihat pada TABEL I.

TABEL I. DAFTAR ENTITAS DAN ATRIBUT

\begin{tabular}{|c|c|c|c|}
\hline No & Proses & Entitas & Atribut \\
\hline \multirow[t]{3}{*}{1} & \multirow[t]{3}{*}{$\begin{array}{l}\text { Penetapan } \\
\text { Kurikulum }\end{array}$} & Kurikulum & $\begin{array}{l}\text { kode_Kurikulum, } \\
\text { tahun_Kurikulum, } \\
\text { profil_Lulusan, } \\
\text { jumlah_SKS, dan } \\
\text { jumlah_JPM }\end{array}$ \\
\hline & & Matakuliah & $\begin{array}{l}\text { kode_mtk, nama_mtk, } \\
\text { sks, jpm, prasyarat, } \\
\text { capaian_pembejaran, } \\
\text { keterangan }\end{array}$ \\
\hline & & RPS & $\begin{array}{l}\text { kode_pertemuan, } \\
\text { jumlah_jam, } \\
\text { capaian_pembejaran, } \\
\text { materi, metode, } \\
\text { referensi }\end{array}$ \\
\hline 2 & $\begin{array}{l}\text { Penetapan } \\
\text { Kalender } \\
\text { Akademik }\end{array}$ & $\begin{array}{l}\text { Kalender } \\
\text { akademik }\end{array}$ & $\begin{array}{l}\text { Tahun_Akademik, } \\
\text { semester, } \\
\text { Nama_Kegiatan, } \\
\text { Tgl_mulai, Tgl_akhir, } \\
\text { dan keterangan }\end{array}$ \\
\hline 3 & $\begin{array}{l}\text { Penetapan } \\
\text { semester dan } \\
\text { Tahun } \\
\text { Akademik }\end{array}$ & $\begin{array}{l}\text { data } \\
\text { akademik }\end{array}$ & $\begin{array}{l}\text { kode_tahun_akadmek, } \\
\text { tahun_akademik dan } \\
\text { semester }\end{array}$ \\
\hline 4 & $\begin{array}{l}\text { Proses } \\
\text { penetapan } \\
\text { dosen } \\
\text { pengampu }\end{array}$ & Dosen & $\begin{array}{l}\text { NIP, nama_dosen, } \\
\text { alamat, gol, jafung, } \\
\text { pendidikan, homebase }\end{array}$ \\
\hline \multirow[t]{3}{*}{5} & $\begin{array}{l}\text { Proses } \\
\text { penyusunan } \\
\text { jadwal } \\
\text { perkuliahan } \\
\end{array}$ & $\begin{array}{l}\text { jadwal } \\
\text { perkuliahan }\end{array}$ & $\begin{array}{l}\text { kode_jadwal, } \\
\text { jam_mulai, } \\
\text { jam_selesai }\end{array}$ \\
\hline & & kelas & $\begin{array}{l}\text { kode_Kelas, } \\
\text { nama_Kelas, } \\
\text { keterangan }\end{array}$ \\
\hline & & $\begin{array}{l}\text { Ruang } \\
\text { Kuliah }\end{array}$ & $\begin{array}{l}\text { kode_ruang, } \\
\text { nama_ruang, } \\
\text { kapasitas, } \\
\text { status_ruang }\end{array}$ \\
\hline \multirow[t]{3}{*}{6} & \multirow[t]{3}{*}{$\begin{array}{l}\text { Proses } \\
\text { Pelaksanaan } \\
\text { Perkuliahan }\end{array}$} & Absensi & $\begin{array}{l}\text { tgl_kuliah, } \\
\text { status_kehadiran, } \\
\text { keterlambatan }\end{array}$ \\
\hline & & Perkuliahan & $\begin{array}{l}\text { tgl_kuliah, materi, dan } \\
\text { metode }\end{array}$ \\
\hline & & $\begin{array}{l}\text { Perusahaan } \\
\text { PKL }\end{array}$ & $\begin{array}{l}\text { : kode_perusahaan, } \\
\text { nama_perusahaan, } \\
\text { no_telp, } \\
\text { alamat_perusahaan } \\
\text { dan MoU }\end{array}$ \\
\hline
\end{tabular}




\begin{tabular}{|c|c|c|c|}
\hline \multirow[t]{6}{*}{ No } & Proses & Entitas & Atribut \\
\hline & \multirow{5}{*}{$110 \mathrm{ses}$} & $\begin{array}{l}\text { Mahasiswa } \\
\text { PKL }\end{array}$ & $\begin{array}{l}\text { judul, } \\
\text { pembimbing_perusaha } \\
\text { an dan status }\end{array}$ \\
\hline & & $\begin{array}{l}\text { Mahasiswa } \\
\text { Skripsi }\end{array}$ & $\begin{array}{ll}\text { atribut } & \text { judul, } \\
\text { tgl_pengajuan, } & \\
\text { proposal, } & \\
\text { usulan_dospem } & \text { dan } \\
\text { biaya } & \end{array}$ \\
\hline & & Bimbingan & $\begin{array}{l}\text { tgl_bimbingan dan } \\
\text { materi }\end{array}$ \\
\hline & & $\begin{array}{l}\text { status } \\
\text { skripsi }\end{array}$ & $\begin{array}{lll}\text { atribut tanggal dan } \\
\text { status }\end{array}$ \\
\hline & & Mahasiswa & $\begin{array}{l}\text { NIM, nama_lengkap, } \\
\text { alamat, no_hp, } \\
\text { namaortubpk, } \\
\text { namaortuibu, } \\
\text { alamatortu, nohportu }\end{array}$ \\
\hline \multirow[t]{2}{*}{7} & \multirow[t]{2}{*}{$\begin{array}{l}\text { Proses } \\
\text { evaluasi } \\
\text { akademik }\end{array}$} & Soal & $\begin{array}{lr}\text { kode_soal, } & \text { kategori, } \\
\text { dan soal. Entitas ini } \\
\text { akan berelasi dengan } \\
\text { kelas, } \\
\text { matakuliah dan tahun } \\
\text { akademik }\end{array}$ \\
\hline & & Nilai & $\begin{array}{l}\text { nilai_absensi, } \\
\text { nilai_UTS, nilai_UAS, } \\
\text { Nilai_Tugas, } \\
\text { persentase_nilai_absen } \\
\text { si, } \\
\text { persentase_nilai_UTS, } \\
\text { persentase_nilai_UAS } \\
\text { dan } \\
\text { persentase_nilai_Tuga } \\
\text { s. }\end{array}$ \\
\hline
\end{tabular}

\section{Model Data Logical}

Gambar 2 merupakan Model Data Logical yang menggambarkan semua Entitas Data yang ada pada sistem database terpadu untuk mendukung monitoring dan evaluasi perkuliahan mahasiswa. Pada model tersebut juga tergambar bagaimana satu entitas data berelasi dengan entitas data lainnya. Relasi ini diperlukan karena untuk menghasilkan sebuah laporan akademik perlu mengambil atau membaca data dari beberapa entitas data yang saling berhubungan. Sebagai contoh Entitas mahasiswa akan berelasi dengan entitas Prodi untuk mengetahui mahasiswa tersebut mengambil program studi apa. Entitas mahasiswa juga berelasi dengan entitas kelas untuk mengetahui mahasiswa tersebut berada di kelas apa. Entitas mahasiswa juga berelasi dengan entitas Absen untuk melihat kehadiran mahasiswa.

\section{Model Data Relasional}

Gambar 3. Model Data Relasional merupakan suatu model basis data yang menggunakan tabel dua dimensi, yang terdiri atas baris dan kolom untuk menggambarkan sebuah entitas data. Pada model ini setiap entitas data digambarkan lebih rinci dengan mendefinisikan primary key, foreign key, tipe data untuk masing-masing atribut, sehingga memudahkan untuk implementasinya.

\section{E. Implemetasi database Terpadu}

Hasil rancangan diimplementasikan menggunakan software database management system Oracle 18c. Proses implementasi mengikuti tahapan dari perangkat lunak tersebut. Proses implementasi terdiri dari pembuatan tabel, pembuatan index, pembuatan sequence, pembuatan constraint. TABEL II merupakan implementasi database terpadu untuk tabel Mahasiswa dan Kurikulum.

TABEL II. IMPLEMTASI DATABASE

\begin{tabular}{|c|c|}
\hline Tabel & Syntax DDL \\
\hline Mahasiswa & $\begin{array}{l}\text { CREATE TABLE mahasiswa ( } \\
\text { nim VARCHAR2(12) NOT NULL, } \\
\text { nama_lengkap VARCHAR2(60) NOT NULL, } \\
\text { tgl_lahir_ DATE NOT NULL, } \\
\text { tempat_lahir VARCHAR2(25) NOT NULL, } \\
\text { jns_kelamin VARCHAR2(10) NOT NULL, } \\
\text { no_telp_INTEGER NOT NULL, } \\
\text { alamat VARCHAR2(30) NOT NULL, } \\
\text { mahasiswaskripsi_mahasiswaskripsi_id } \\
\text { NUMBER NOT NULL, } \\
\text { ortusiswa_ortusiswa_id } \\
\text { NULL, } \\
\text { kelas_kode_kelas VARCHAR2(6), } \\
\text { prodi_kode_prodi VARCHAR2(6) NOT NULL); } \\
\text { CREATE UNIQUE INDEX mahasiswa_idx ON } \\
\text { mahasiswa ( } \\
\text { mahasiswaskripsi_mahasiswaskripsi_id } \\
\text { ASC ); } \\
\text { CREATE UNIQUE INDEX mahasiswa_idxv1 ON } \\
\text { mahasiswa ( } \\
\text { ortusiswa_ortusiswa_id } \\
\text { ASC ); } \\
\text { ALTER TABLE mahasiswa ADD CONSTRAINT } \\
\text { mahasiswa_pk PRIMARY KEY ( nim ); }\end{array}$ \\
\hline Kurikulum & $\begin{array}{l}\text { CREATE TABLE kurikulum ( } \\
\text { kode_kurikulum VARCHAR2(10) } \\
\text { NOT NULL, } \\
\text { thn_kurikulum INTEGER NOT } \\
\text { NULL, } \\
\text { profile_lulusan CLOB NOT NULL, } \\
\text { tot_sks_teori INTEGER NOT NULL, } \\
\text { tot_sks_praktek INTEGER NOT } \\
\text { NULL, } \\
\text { tot_jpm_teori INTEGER NOT NULL, } \\
\text { tot_jpm_praktek INTEGER NOT } \\
\text { NULL } \\
\text { ); } \\
\text { ALTER TABLE kurikulum ADD } \\
\text { CONSTRAINT kurikulum_pk PRIMARY } \\
\text { KEY (kode_kurikulum ); }\end{array}$ \\
\hline
\end{tabular}

\section{F. Pengujian database}

Pengujian database bertujuan untuk memastikan kesesuaian dengan kebutuhan bisnis. database diuji dengan menggunakan metode Unit Testing. Pengujian dilakukan secara random, untuk memastikan kolom-kolom dan konstrain-konstrain bekerja sesuai dengan rancangan database. 
Pengujian memiliki tiga jenis yaitu black box testing, white box testing dan grey box testing[12] .

Tahapan pengujian mencakup pembuatan rancangan pengujian dan menjalankan rancangan pengujian tersebut. Pengujian black box dilakukan pada antar muka aplikasi tanpa harus berinteraksi dengan basis data secara langsung. Pengujian white box memerlukan pengetahuan penguji pada sistem basis data, termasuk souce code. pengujian jenis white box dilakukan terhadap komponen berikut:
a. Pengujian konstrain Primary Key
b. Pengujian konstrain NOT NULL
c. Pengujian konstrain $U N I Q U E$
d. Pengujian konstrain References
e. Pengujian Trigger
f. Pengujian Sequence

Pengujian dilaksanakan dengan menggunakan enam belas skenario. Skenario pengujian dibuat secara random/ acak tetapi melingkupi seluruh object dan konstrain yang ada. TABEL III merupakan hasil dari pengujian.

TABEL III. HASIL PENGUJIAN

\begin{tabular}{|l|l|l|c|c|}
\hline \multirow{2}{*}{ No } & \multirow{2}{*}{$\begin{array}{c}\text { Kategori } \\
\mathbf{U j i}\end{array}$} & \multicolumn{1}{|c|}{ Nama } & $\begin{array}{c}\text { Jumlah } \\
\mathbf{U j i}\end{array}$ & Hasil \\
\hline 1 & \multirow{2}{*}{$\begin{array}{l}\text { Pengujian } \\
\text { Konstrain }\end{array}$} & PRIMARY KEY & 4 & diterima \\
\cline { 3 - 5 } & & NOT NULL & 4 & diterima \\
\cline { 3 - 5 } & REFERENCES & 4 & diterima \\
\cline { 3 - 5 } & UNIQUE & 1 & Diterima \\
\hline 2 & $\begin{array}{l}\text { Pengujian } \\
\text { Sequence }\end{array}$ & SEQUENCE & 2 & Diterima \\
\hline 3 & $\begin{array}{l}\text { Pengujian } \\
\text { Index }\end{array}$ & INDEX & 1 & Diterima \\
\hline 4 & $\begin{array}{l}\text { Pengujian } \\
\text { Trigger }\end{array}$ & $T R I G G E R$ & 1 & Diterima \\
\hline
\end{tabular}

Hasil pengujian menunjukkan nilai sesuai dengan rancangan skenario uji database ini berarti bahwa database akademik yang terbentuk dapat menyediakan data dan informasi untuk monitoring dan evaluasi perkuliahan. Database ini ke depannya juga dapat digunakan untuk untuk menganalisis, prilaku dan performance mahasiswa [5] serta untuk memprediksi performance mahasiswa[6].

Prediksi performance akademik mahasiswa sangat penting untuk lembaga pendidikan karena program-program strategis dapat direncanakan untuk meningkatkan atau mempertahankan performance mahasiswa selama masa studi mereka [7].

\section{KESIMPULAN}

Penelitian ini mengasilkan sebuah sistem database akademik terpadu untuk mendukung monitoring dan evaluasi perkuliahan mahasiswa. Analisis kebutuhan menghasilkan 8 proses utama pada kegiatan akademik. Dari proses tersebut menghasilkan 25 entitas data yang diimplementasi menjadi 45 tabel. Tahap pembuatan model data menggunakan bantuan software data modeller yang memiliki kemampuan reverse engineering.

Implementasi model relasional menjadi model fisik menghasilkan sintaks program SQL berisi create tabel, create index, create trigger, constraint dan sequence. Skenario pengujian dibuat sebanyak enam belas skenario besar untuk menguji hasil implementasi. Hasil pengujian menunjukkan bahwa database akademik yang terbentuk dapat menyediakan data dan informasi untuk monitoring dan evaluasi perkuliahan

Database akademik ini dapat dikembangkan lebih lanjut dan dan dapat dimanfaatkan di masa mendatang sebagai sumber data untuk melakukan analisis dan prediksi kinerja akademik mahasiswa. Ini akan membantu program studi untuk merencanakan program-program yang tepat guna meningkatkan kinerja akademik mahasiswa. 


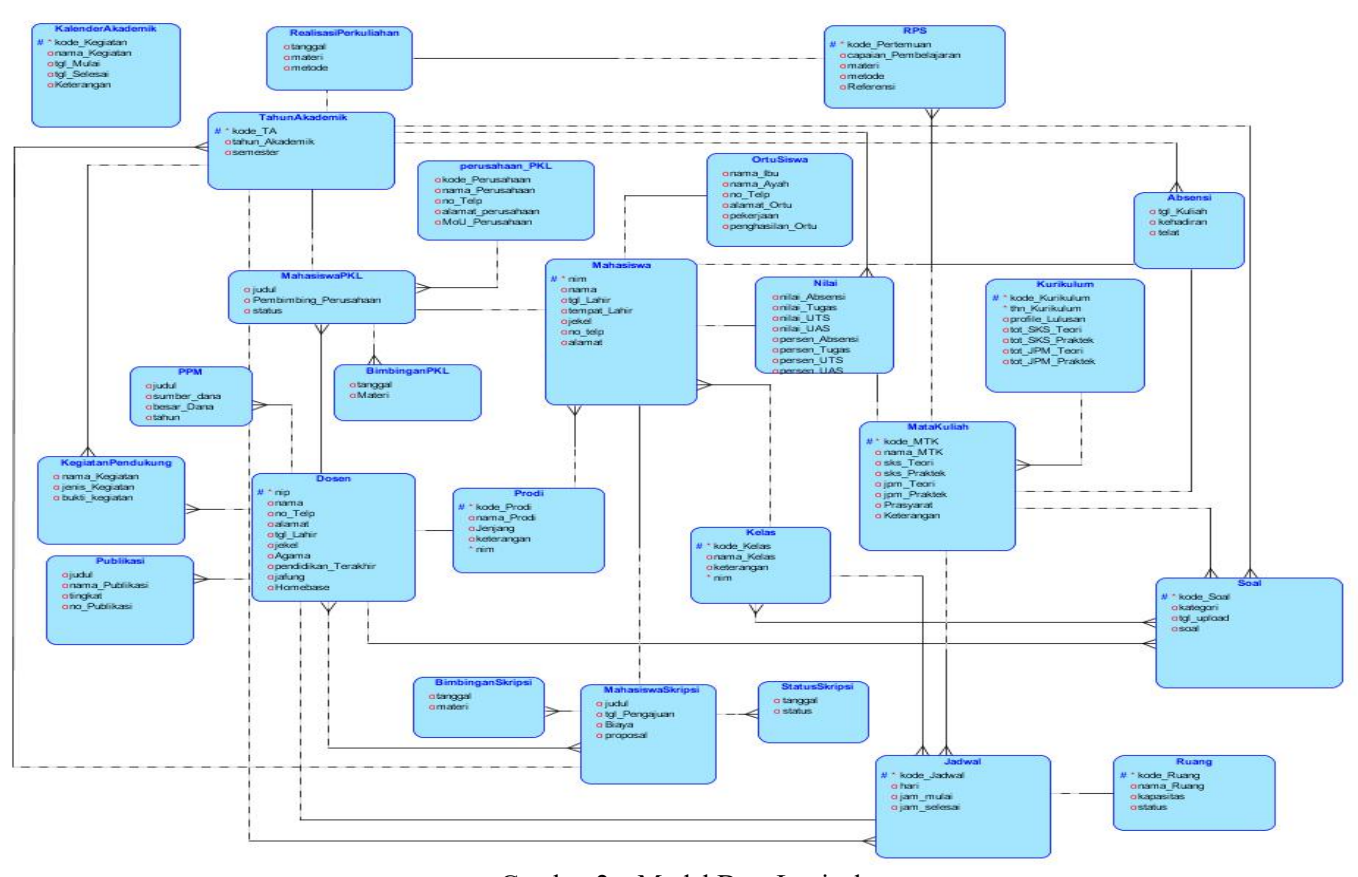

Gambar 2. Model Data Logical

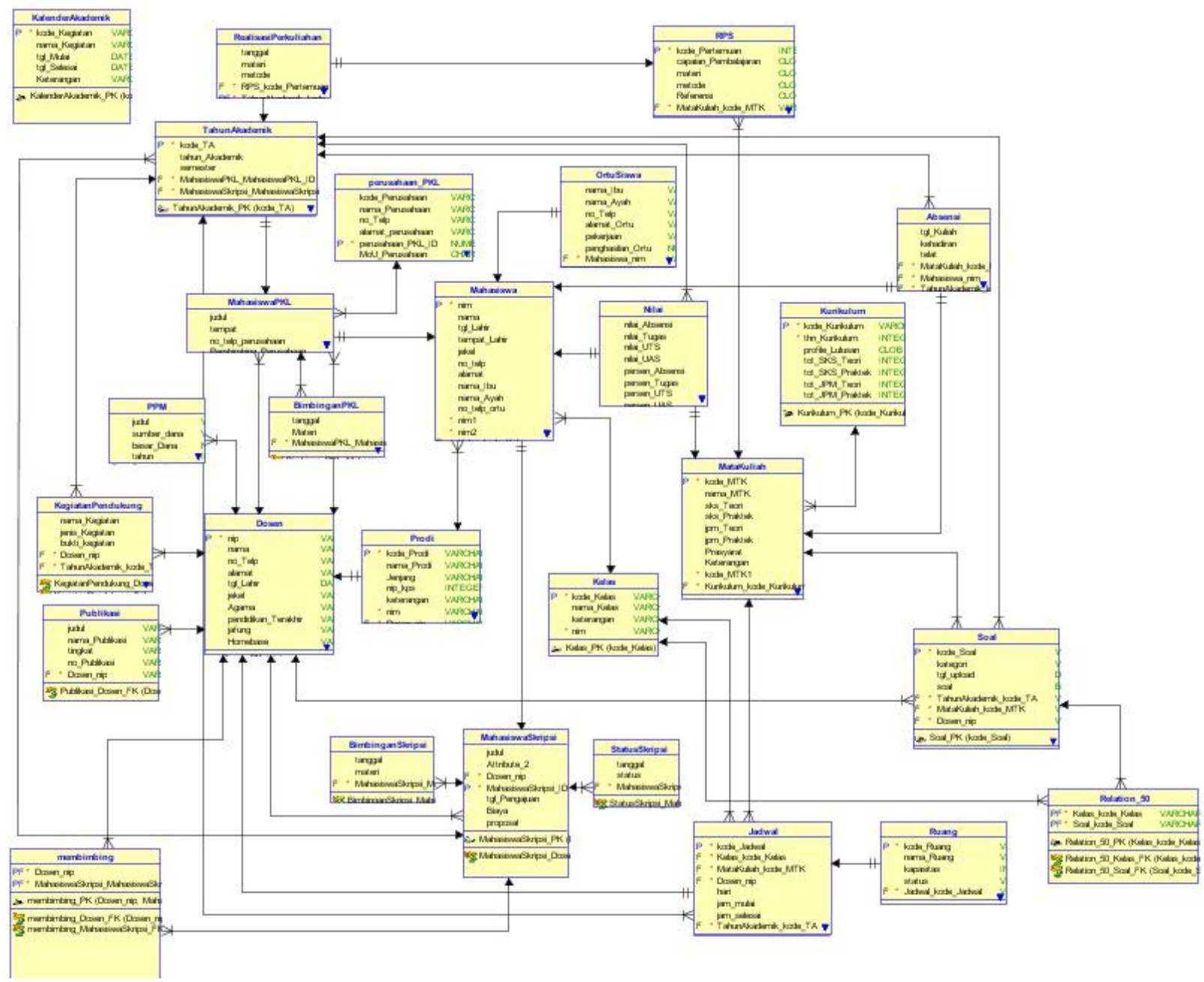

Gambar 3. Model data Relasional 


\section{REFERENS}

[1] A. Sripriya and R. Dhanapal, "Mobile software solutions using mobile database design methodology," 2010 2nd Int. Conf. Comput. Commun. Netw. Technol. ICCCNT 2010, 2010 .

[2] Laudon, Management Information Systems THIRTEENTH EDITION GLOBAL EDITION. 2014.

[3] M. Mansur and K. Kasmawi, "Pengembangan Sistem database Terpadu Berbasis Web Untuk Penyediaan Layanan Informasi Website Desa," J. Nas. Teknol. dan Sist. Inf., vol. 3, no. 1, pp. 73-82, 2017.

[4] M. Ida, "Structure of university database system and data analysis," Int. Conf. Adv. Commun. Technol. ICACT, pp. 553-557, 2014.

[5] M. M. Kurdi, H. Al-Khafagi, and I. Elzein, "Mining educational data to analyze students' behavior and performance," Proc. 2018 JCCO Jt. Int. Conf. ICT Educ. Training, Int. Conf. Comput. Arab. Int. Conf. Geocomputing, JCCO TICET-ICCA-GECO 2018, pp. 171-175, 2018.

[6] F. Aman, A. Rauf, R. Ali, F. Iqbal, and A. M. Khattak, "A Predictive Model for Predicting Students Academic Performance," 10th Int. Conf. Information, Intell. Syst. Appl. IISA 2019, pp. 2-5, 2019.

[7] J. Denny, M. M. Rubeena, and J. K. Denny, "A Noval Approach For Predicting The Academic Performance Of Student," Proc. 2019 3rd IEEE Int. Conf. Electr. Comput. Commun. Technol. ICECCT 2019, 2019.

[8] Z. A. Al-Maawali, H. Noronha, and U. Prakash Kumar, "Big data acquisition, preprocessing and analysis to Develop and Implement Effective database System with High Security Standards," 2019 4th MEC Int. Conf. Big Data Smart City, ICBDSC 2019, 2019.

[9] T. Connolly, "database Systems A Practical Approach to Design, Implementation, and Management Fourth Edition," Addison Wesley, Engl., no. June 2014, 2005.

[10] H. K. Al-Masree, "Extracting Entity Relationship Diagram (ERD) From Relational database Schem," Int. J. database Theory Appl., vol. 8, no. 3, pp. 15-26, 2015.

[11] P. P. Oleynik and V. I. Gurianov, "User UML-profile and metamodel-driven design of database applications," 2016 Dyn. Syst. Mech. Mach. Dyn. 2016, 2017.

[12] I. Sommerville, Software Engineering. 2013. 